\title{
Theories and Contemporary Development of Organizational Perspectives in Social Sciences. Feminist approach to organizational analysis. Part 3
}

\author{
Medani P. Bhandari ${ }^{1}$ \\ ${ }^{1}$ Akamai University \\ Hawaii - USA
}

\begin{abstract}
This paper is purely theoretical in which I have illustrated the contributions of the founding theorist of Western sociology, by focusing on how they addressed (or didn't address) organizations. Then, I have discussed (in brief) the development of organizational theory and how organizational theorists are responding to the emergence of challenges to the traditional rational approaches to understanding organizations. These analyses are situated on the historical contexts include major contributions of each theorist. This research is solely based on the secondary information. Paper contents four Sections: first the work of the three founding theorists of Western Sociology, Karl Marx; Émile Durkheim and Max Weber, secondly, I have exemplified the development of organizational theory and the emergence of challenges to the traditional rational approaches to understand the organization; where $I$ have analyzed the work of Classical theorists- Max Weber, Henri Fayol, Frederick Taylor, Luther Halsey Gulick, Herbert A. Simon, Berton H. Kaplan, modern theorist- Michel Foucault, Jurgen Habermas, Jacques Derrida, Jurgen Habermas etc. Third Section covers the contemporary theories and perspectives. In this section I have exemplified how Philip Selznick, Peter Blau, James David Thompson and Charles Perrow incorporated the Weber notion of bureaucracy followed by DiMaggio, Paul, J. and Walter W. Powell etc. and in forth section, covers the feminist approach in theory building with focus of organizational analysis (with the focus of Arlene Daniels, Dorothy Smith, Marjorie DeVault, Gisela Bock and Susan James, Martha Calas, Linda Smircich etc. work). This paper has detailed footnotes quoted from the original sources and contents useful reference of the sociological theory and practices for concerned social scientist to build their knowledge base and research direction.
\end{abstract}

Index Terms - International Organizations, International Relation, Organizational Sociology, Organizational Theory, Classical Sociology, Contemporary Theories.

ASEJ - Scientific Journal of Bielsko-Biala School of Finance and Law

Volume 24, No 1 (2020), 6 pages

DOI: $10.5604 / 01.3001 .0014 .1344$

Received: 06 April 2020; Accepted: 10 April 2020

\section{INTRODUCTION}

Arlene Daniels 1975:349 states that "The women's movement contributes far more to sociology than a passing interest would. The development of a feminist perspective in sociology offers an important contribution to the sociology of knowledge. And through this contribution, we are forced to rethink the structure and organization of sociological theory in all the traditional fields of theory and empirical research" (as cited by Stacey and Thorne 1985). Daniels captures the notion of feminist movements, which I think presents a major turn, not only to change the directions women face in the 20th century onwards but also to provide a ground for the development of feminist scholarship. Adding to this notion, Tracy and Thorne (1985) bring a very important account of how sociology was developed by the privileged western, white, upper-middle class, heterosexual men. This hegemony of the male began to be challenged; however, it was not a very strong stand until the feminist movements began at organized level.

The foundation was developed through the first wave of feminism movements. The first wave made a difference to the women's stand to some extent; however formally this stand became more visible only since the 1960s. Since then, the onesided view of society (privileged western, white, upper-middle class, heterosexual men) has been challenged by the various feminist scholars, including postmodern thinkers. This challenge brought a new way to examine society. Academicians began to examine society in a more open and flexible way, which helped to develop new thoughts and theories relating to feminism, racism etc. Within sociology, scholars began to see society deeply through feminist perspectives (Dorothy Smith,

Regular research paper: Published 30 April 2020

Corresponding author's e-mail: medani.bhandari@gmail.com

Copyright (C) 2018 This is an open access article distributed under the Creative Commons Attribution CC-BY-NC 4.0 License. 
Marjorie DeVault, Gisela Bock and Susan James). In organizational sociology new perspectives have been developed (rational, natural and open system (primarily) and environmental, demographic and ecological etc. more recently). At first the women's standpoint in the organization was not much focused upon, as discourse dealt more often with women's freedom as individuals as the feminisms movement began to examine the women's stand in every sector of social life including formal and informal social organizations, scholars began to see the women's role in organizational structure. There are several authors in feminist scholarship who have contributed to organizational theory development. In this essay, I will only focus Martha Calas and Linda Smircich's contribution to organizational theory building. They primarily examine women's standing in organizational management and apply a postmodern perspective to analyze the organization based on the perspectives developed by Michel Foucault, Jurgen Habermas, Jacques Derrida, Jurgen Habermas etc.

Martha Calas and Linda Smircich state that organization theories - once they are presented as knowledge - guide organizational participants in their efforts to understand and control organizations. In this sense organizational scientists 'make' organizations as much as we study them, thus having a socially conscious organizational practice may depend first on having a more socially conscious organizational scholarship (Calás \& Smircich 1992, pp. 223, 234). These authors' approach to organization study is particularly based on postmodern notions of thought. They analyze organizations in various perspectives and provide a detailed account of the functionalist liberal way to postmodern power dynamism. I think Foucault's notion of power politics and social change through knowledge is a relevant ground for them to examine organizational dynamism. Because of the changing faces of organizations within modern neo-liberal socio-economic scenarios it is hard to develop universal principles for organization management. Calás and Smircich's analysis goes beyond traditional sociological scholarship which was silent about women's standing and roles in the organization, and elaborate on how women are still largely ignored, or at least passed over, in organizational power politics. Another aspect they have analyzed is the impact of colonialism to the developing world's organizations.

\section{FEMINIST APPROACH}

In the following paragraphs I will examine how these two authors view feminism in organizational management and what they have contributed to organizational theory development.

Calás and Smircich (1996) state that the word "feminism" cannot contain the notion of the strength of feminist theory, because it includes several perspectives, hence it should be "feminisms". This minute currection encapsulates the seriousness of their stand. Another point they state is "feminist theories go beyond 'women's issues' where they examine feminisms as critical and political issues, which have been embedded in society since earliest times and can be seen in every aspect of social, economic and political spheres. They argue that feminist theorists should situate themselves as a part of any project "in research" to articulate the real grounds of tension. Authors are not satisfied with the existing theory of feminisms which according to them are not necessarily in sequential order. They state that theories of feminisms have built on, responded, and changed as a result of different dialogues boundaries between them are "blurry and blurring". They look into existing organizational theories through feminist perspectives and evaluate how feminisms contribute to organization theory building in the context of existing liberal, radical, psychoanalytic, Marxist, socialist, poststructuralist/ postmodern and third world/(post) colonial perspectives.

Calás and Smircich (1996) explain each of these categories, which, in my opinion, provide a very important basis for how organizations can be analyzed and explained. The following paragraphs give a brief account of such points, developed by Calás and Smircich, which can be used in studying social organizations. Similarly, their liberal perspective is based on the functionalist/positivist approach, which mostly examines sex and gender as a variable, not a framework for organizational analysis. At individual and psychological level, this approach examines the sex and gender differences in leadership, power, job stress, satisfaction, organizational commitment, sex stereotypes, androgyny, recruitment, selection and performance appraisal. It also examines the glass ceiling, organizational demography, careers building and social networks and evaluates whether organizations provide equal opportunity and take affirmative action without discrimination to the women workers in the organizations. Calás and Smircich are analyzing the situation of women in organizational management around 1996, and where women stand more than ten years later is not presently clear.

Likewise, the radical feminist approach uses case studies and ethnographies to examine organizations, and search for new ideas of alternative organizations that may arise for the creation of "woman space". Calás and Smircich (1996) illustrate Koen's five alternatives to increase women's role in organizations such as participatory decision making, rotating leadership, flexible and interactive job designs, and equitable distribution of income, interpersonal and political accountability. However, they question whether it is possible in the real ground to apply these principles or not. Here questions arise, such as who actually heads the organization for whose interest? While most organizations still operate with the traditional functional system of governance, whether this new radical approach can take a forward step? These authors are silent about the implementation part. Another approach they reveal is psychoanalytic. Here they state that organizational study should examine whether women have equal advantages in the organization or not, in terms of leadership and teamwork capabilities. This approach "considers the consequences of women's different psychosexual development for their roles in organization and management" (Calás\& Smircich 1996, p. 224). The psychoanalytic aspects of organizational study have been little considered in practice. Many scholars have analyzed organizational behavior; however, they have seldom adequately represented the essential differences governing women's standpoint and roles. 
Calás and Smircich (1996) next elaborate on the Marxist approach, where they criticize capitalism and patriarchy together: "work organizations are important sites for analysing the ongoing reproduction of sex/gender inequality as they expose the intersections of patriarchy and capitalism" (Calás \&Smircich 1996, p. 226). They state that the socialist approach of organizational research examines the case studies of "women in the organization". In this approach organization studies do not distinguish individuals from private and public life: "families and societies are mutually constituted through gender relations" (Calás \&Smircich 1996, p. 227).

This approach is opposite to Max Weber's notion of the bureaucratic model. As Kilduff and Mehra (1997) notes: "Feminist postmodern researchers seek to represent women as subjects rather than objects and to give voice to the narratives of those who violate what Cassell (1996: 46) referred to as the "principles of the incarnate social order" (Kilduff and Mehra 1997, p. 472). However, traditional bureaucratic expositions reject this notion. Feminist scholars criticize the traditional organizational model because it focuses on power in the hierarchical order which is silent about the women's stand in the decision-making process. I think an alternative model can be proposed on the basis of dialectical classification (in terms of gender, sex, race, ethnicity and country of origin) and where organizations can be analyzed in the context of sex/gender, north and south or as a power struggle.

Calás and Smircich further explore the subject from the poststructuralist/postmodern perspective. This approach is based on power relationships. They state that postmodern feminist ethnography "subverts many images about what it is to be a gendered self-belonging to particular ethnic groups within particular life circumstances; as well as what counts as theory and where the boundary is between the empirical and the theoretical" (Calás \& Smircich 1996, p. 231) and note poststructuralist study of "secretaries as a social group and their discursive constructions in the day-to-day relationships of power" (Calás \& Smircich 1996, p. 231). Calás and Smircich' postmodern approach mainly examines the women's role in the organization in terms of power politics. In the bureaucratic web, power is considered a major aspect to handle the operation of the organization. In this context, to study organizations from any perspectives it is important to see that how the organization is structured and who makes the decisions.

The final approach they propose is the study of the third world's perspective, which is still a new approach that focuses on how the organization or agency is formed and how knowledge is created within it. Organizational study is mainly dominated by the western scholars. Scholars are silent about the developing world situation on "how organizations are created, operated, and how they function". Another silent feature is the changing face of the third world's organizations in the post colonialism condition. Calás and Smircich highlight this issue and state that knowledge developed by third world women is still not for them (as I have observed, too often the benefits of financial and other aid benefit disproportionally the donor country rather than the recipient). Chandra Mohanty (1988) examines how western eyes see the women of color in the
United States. She states "I would like to suggest that the feminist writings I analyse here discursively colonize the material and historical heterogeneities of the lives of women in the third world, thereby producing/ representing a composite, singular 'third-world woman' - an image which appears arbitrarily constructed but nevertheless carries with it the authorizing signature of western humanist discourse (Mohanty 1988 , p. 63). Her focus was to see how third world's women are examined from western eyes. She argues that the third world is facing western hegemony in various ways. Mohanty's notion is valid even to propose alternatives in the feminist discourses. I think this sector needs to be examined more deeply through a comparative study of how southern women are changing their stand in society. As far as I know women's participation in the decision-making process is still very limited. Calás and Smircich insist that the western world needs to explore more about women's role in the southern context.

Calás and Smircich are considered as feminist and postmodern organizational theorists (Brewis 2005). They examine organizations in two major frames:

1) feminisms and

2) modernism and postmodernism.

In the feminisms perspectives they bring the notion of how identity makes difference in organizations due to sex, class and culture. The identity issue not only applies in the organizational setting but equally works with other social behavior. In the organizational setting, Calás and Smircich bring three basic points about identity i.e. - it constitutes a racial term and condition of employment, - it is a form of race-plus discrimination, -and it reflects racial stereotyping. The question arises, then, how to address such an issue. Here the authors lack clarity.

It is worthwhile to evaluate what Calás and Smircich have added in organizational theory. In this context, Brewis (2005) summary of Calás and Smircich's organizational theory is useful to quote. Calás and Smircich present a valid argument to apply postmodern perspectives in organizational study. I am not a fan of the postmodern approach, but in researching the place where women stand in organizations, their points provide some assistance.

In the context of the postmodern approach to organizational research, Foucault's power dynamism is the major ground for Calás and Smircich. However, the postmodern approach itself is not universally accepted in organizational research. Calás and Smircich (1999) advocate postmodern thought, in their words: "Insofar as postmodern perspectives allow for questioning conventional approaches to theory development, the argument goes; they provide incisive analyses showing the inner workings and assumptive basis of those theories. At the same time, however, the elusiveness of theory under postmodern premises prevents those who articulate postmodern perspectives from theorizing other, alternative views, because they do not have any "solid ground" from which to speak" (Calás and Smircich 1999, p. 649). These accounts of postmodern thought provide a ground to go for the application of postmodern perspectives in sociological research (in my case organizational research). In institutional research the 
application of the reflexive perspective exists (e.g. Erving Goffman's Asylum etc.). Nevertheless, formal organizations are still operating with a basis in the traditional bureaucratic system. I think it is not impossible to use the postmodern perspective, but until there is wider adoption and documentation of organizations operating in new ways it is certain to be difficult for me to find the appropriate information.

\section{CONCLUSION}

Organizational sociology is one of the recent subfields which is founded on the basis of philosophy developed by western authors Durkheim, Marx, and Weber. Marx provides the procedure to manage the organizational labor on the basis of dialectical materialism (socialism). Durkheim as a functionalist discusses the division of labor as normal social mechanism (social ethics and religion) and Weber focuses on the trend of rationalization in organization governance in both the public and private sectors of modern societies (rationalism and capitalism). The theories Marx and Weber focus on how society can produce more goods and services to fulfill social needs through formal forms of organizations. Marx talks about the statelessness situation through the labor movement, while Weber says this is shallow imagination. Among these three major sociologists Weber is considered as the one of the founding fathers of organizational sociology, he developed the rational approach to the analysis of bureaurocracy. According to Collins (Collins1986, p.286) "there is nothing better known in the field of organizations, perhaps in all of sociology, than Weber's model of bureaucracy.

It also happens that there is no more complete misunderstand of major sociological theory than the way Weber's organizational theory was treated in American Sociology" (Scott 2003, p. 43). Needless to state that Weber's contribution is paramount in organizational sociology. Weber focuses on the standard interpretation of society and examines sociology as a comprehensive science of social action. Weber provides a model of the bureaucracy the services the organization. In addition to Max Weber, organization sociology is also influenced by the classical organizational theorists such Frederick W. Taylor (scientific management or organization), Henri Fayol (administrative theory of organization), and Herbert A. Simon (Administrative behavior) (Scott 2003, p 3853). The major contemporary authors of organizational sociology (Philip Selznick, Peter Blau to Charles Perrow, Paul DiMaggio and Walter Powell etc.) follow the Weberian rational philosophy (including Taylor, Fayol and Simon) to analyze the formal organizations one way or another. Organizational sociology has three major perspectives - rational, natural and open systems.

On the basis of these major perspectives contemporary sociologists have developed several theories and methods grounded in the classical roots, but with new models (Kuhn 1962; Burrell\& Morgan 1979; Morgan 1980; Ness and Brechin 1988; Taylor 2002; Scott 2003). Organizations are formed by the contexts or environments in which they are established. Modern organizations replicate the impact of their historical origins in societies characterized by growing privileged circumstances and conflicts over the control and distribution of products and services. Organizations come in many puzzling forms because they have been clearly designed to deal with a wide range of social, cultural, economic and political problems. Because they have emerged under widely varying environmental conditions, they have to deal with complexity within and emerged externalities. Therefore, there is no limitation of theoretical approaches and their applications in organizational analysis.

There are a range of paradigms (ontology, epistemology and methods as well as the positivism to constructivism) used to examine organizations such as in terms of power dynamism, culture, networks (within organizations and with individuals) or population or ecological perspectives with the application of both qualitative and quantitative methods. Organizational theory also examines the bureaucratic order within the organization and evaluates how individuals interact in or with organizations and maintain their role to administer the organization. It also analyses the control mechanism, its model (particularly bureaucratic), and explains how such modality works in terms of product and production delivery to the society. Therefore, organizational study deals with multidimensional and complex phenomena and it is not possible to capture the complete social environment where they originate, operate and function.

Postmodern, Marxist and feminist authors have been challenging this western notion of organizational theory. They argue that classical and rational organizational theories are not complete because first they hold mostly western white male perspectives and secondly, they only minimally consider the workers' perspectives (and I agree with this criticism). Feminist approaches of organizational study, which follow the rational, natural and open system perspectives of organizational analysis, challenge the traditional Weberian notion of bureaucracy. They follow Foucault's postmodern perspectives to analyze formal organizations. The contribution of Arlene Daniel, Martha Calas, Linda Smircich and Jana Brewis et al contributions are exemplary works of this kind illustrated in this essay. I think the concept of formal organization, is not only a western product, however, southern perspectives are only very marginally included in the organizational studies (Mohanty 1986; Spivak 1990). "There are overlaps of theories and paradigms among international relations theory, sociological theory, organizational theory, and international organization theory. Literature is silent on bridging such gaps. Ness and Bechin (1988) have initiated studies to bridge this gap, but there has been no continuation of this effort from the sociological point of view" (Bhandari 2019).

In this connection Bhandari $(2012,2018,2019,2020)$ tried to add new web on the organizational theory, by using multidisciplinary approaches to study the role of International Union of Conservation of Nature (IUCN) and Intergovernmental Panel on Climate Change (IPCC). It is noticed that, there is no collaborative approaches among the organizational sociologist, between US and Europe as well as with the scholars of the rest of the world. The egoism or me 
supremacy has divided social scientists and as much as possible individual scholars are trying to create own niche. As society is moving from collectivism to individualistic paradigms, scholarships also boasting this narrative. As sociologist I follow the principle of "Live and let other live- the harmony with nature /living beings" and "Bashudaiva Kutumbakkam"- The entire world is our home and all living beings are our relatives". All scholars need to acknowledge the fellow scholars prove, support, reject but should not ignore to the built knowledge. This paper is kind of honoring the all pillars of social thoughts by briefly analyzing the knowledge they have provided. There is a strong need of more detail study about the contributions of these world GURUS and need of utilization of their MANTRAS for social the social harmony and development.

I have perhaps provided only a glimmer of understanding about the founding authors of western sociological theories and how organizational theories have been developed, but I have given a general scenario of the available literature and theory, as I have found it. I think there is a need for extensive research on how the western notion of formal organization is viewed in the developing world. And of how western hegemony has contributed to or dismantled the traditionally formed and functioning formal organizations of the developing world.

\section{ACKNOWLEDGEMENT}

I acknowledge the input of Mrs. Prajita Bhandari, for creating a peaceful environment to complete this paper and insightful comments and language editing. I would also like to thank to Prameya, Kelsey, Manaslu, Abhimanyu for their insightful comments. I would also thank to Neena (our granddaughter who brought the joy in the family so, I was able to concentrate on my job). Especial thanks go to Professors Steven R. Brechin, Peter Ibarra, Marjory for their mentorship to me, without their efforts I would not be able to stand as social theorist. I would also like to thank to the Editor in Chief Prof. Jacek Piotr Binda and Associate Editor Aleksander Sapinski for their encouragements to complete this very theoretical paper. I would also like to thank to the reviewer panel for their input and comments.

\section{REFERENCES}

Bhandari, M. P. (2019), Sustainable Development: Is This Paradigm the Remedy of All Challenges? Does Its Goals Capture the Essence of Real Development and Sustainability? With Reference to Discourses, Creativeness, Boundaries and Institutional Architecture, SocioEconomic Challenges, Volume 3 , Issue 4, 97-128 ISSN (print) - 2520-6621, ISSN (online) - 2520-6214 https://doi.org/10.21272/sec.3(4).97-128.2019,

http://armgpublishing.sumdu.edu.ua/wp-content/uploads/2020/01/9.pdf

Bhandari, M. P. (2019), The Debates between Quantitative and Qualitative Method: An Ontology and Epistemology of Qualitative Method- the Pedagogical Development, in Douglass Capogrossi (Ed.) Educational Transformation: The University as Catalyst for Human Advancement, Xlibris Corporation, USA ISBN-10: 179604895X; ISBN-13: 978-1796048957

Bhandari, M. P, (2019), Live and let other live- the harmony with nature /living beings-in reference to sustainable development (SD)- is contemporary world's economic and social phenomena is favorable for the sustainability of the planet in reference to India, Nepal, Bangladesh, and Pakistan? Adv Agr Environ Sci.
(2019);2(1): $\quad 37-57 . \quad$ DOI: $\quad 10.30881 /$ aaeoa.00020 http://ologyjournals.com/aaeoa/aaeoa_00020.pdf

Bhandari Medani P. (2019), "BashudaivaKutumbakkam"- The entire world is our home and all living beings are our relatives. Why we need to worry about climate change, with reference to pollution problems in the major cities of India, Nepal, Bangladesh and Pakistan. Adv Agr Environ Sci. (2019);2(1): 8-35. DOI: $10.30881 /$ aaeoa.00019 (second http://ologyjournals.com/aaeoa/aaeoa_00019.pdf

Brewis, Joanna (2005), Othering Organization Theory: Marta Calas and Linda Smircich, The Editorial Board of the Sociological Review, 2005, Blackwell Publishing, Ltd.

Calas, M.B. and L. Smircich (1996), "From 'The Woman's' Point of View: Feminist Approaches to Organizational Studies" Handbook of Organizational Studies, Sage Publications.

Calás, M. B., L. Smirch (1992a), "Using the 'F' Word: Feminist Theories and the Social Consequences of Organizational Research.” In Albert J. Mills and Peta Tancred (eds), Gendering Organizational Analysis: 222-234. Newbury Park, CA: Sage.

Calás, M. B., L.Smircich (1992b), "Re-writing Gender into Organizational Theorizing: Directions from Feminist Perspectives." In Michael Reed and Michael Hughes (eds), Rethinking Organization: New Directions in Organization Theory and Analysis: 227-253. London: Sage.

Calas, M.B., L. Smircich, (1991), "Using the F word: feminist theories and the social consequences of organizational research", in Mills, A.J., Tancred, P. (Eds), Gendering Organizational Theory, Sage, Newbury Park, CA

Calas, M.B., Smircich, L. (1990), "Re-writing gender into organizational theorizing: directions from feminist perspectives", in Reed, M.I., Hughes, M.D. (Eds), Re-thinking Organization: New Directions in Organizational Research and Analysis, Sage, London.

Cassell, J. (1996), "Feminist Approaches to Software Design: Building Interactive Story Systems for Girls." Small Computers in the Arts Network'96 (Nov, 1996).

Collins, Patricia Hill (1986), Learning from the Outsider Within: The Sociological Significance of Black Feminist Thought, Social Problems, Vol. 33, No. 6, Special Theory Issue (Oct. - Dec., 1986), pp. s14-s32

Kilduff, M., A. Mehra (1997), Postmodernism and Organizational Research, The Academy of Management Review, Vol. 22, No. 2 - 453-481

Spivak, Gayatri C (1999), A Critique of Post-Colonial Reason: Toward a History of the Vanishing Present (Harvard UP, 1999).

Spivak, Gayatri C (1990), The Post-Colonial Critic: Interviews, Strategies, Dialogues. Ed. Sarah Harasym. (London: Routledge, 1990).

Spivak, Gayatri C (1988), "Can the Subaltern Speak?" in Cary Nelson and Larry Grossberg, eds. Marxism and the interpretation of Culture (Chicago: University of Illinois Press, p.271-313.

Spivak, Gayatri C (1988), Selected Subaltern Studies. Ed. with Ranajit Guha, Oxford.

Stacey, J. (1996), In the Name of the Family: rethinking family values in the postmodern age. Boston: Beacon Press.

Stacey, J. (1990), Brave New Families: Stories of Domestic Upheaval in Late Twentieth-Century America. Basic Books.

Stacey, J. (1983), Patriarchy and Socialist Revolution in China. University of California Press.

Stacey, J., Bereaud, S. \& Daniels, J. (Eds.) (1974), And Jill Came Tumbling After: Sexism in American Eduction. Dell.

Thorne, Barrie (1984), "Nomenclature, Gender, and the 1984 Election," Women and Language VIII, No. 1/2 39-40.

Thorne, Barrie, Virginia Powell, Beverly Purrington, Regi Teasley, and Carol Wharton, (1984), "Teaching the Sociology of Sex and Gender," American Sociological Association Teaching Newsletter, 1(4), August 1984, pp. 2-7.

Thorne, Barrie (1982),"Guidelines for Introductory Sociology," in Sex and Gender in the Social Sciences: Reassessing the Introductory Course (Judith M. 
Gappa and Janice Pearce). Washington, D.C.: American Sociological Association Teaching Resources Center, 1982. 